\title{
Evaluating a grief programme offered in primary schools: An Appreciative Inquiry
}

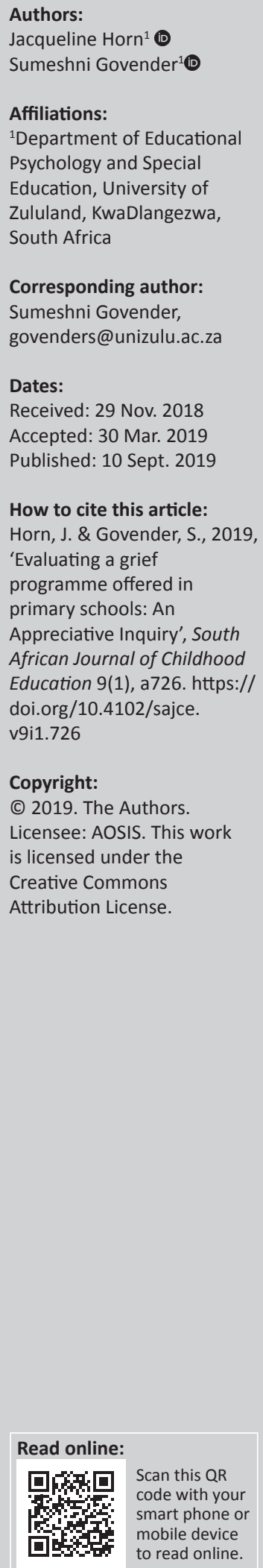

Background: Death and loss are inevitable, and life changes profoundly for those left behind. A General Household Survey by Statistics South Africa indicated that $94.2 \%$ of orphans aged 7-18 years were still attending school. With no parental and often familial support, learners often had to turn to their teachers for support. Vukuzakhe, a non-governmental organisation, saw the need for a grief programme in schools.

Aim: The aim of this study was to evaluate how the school-based grief programme is perceived by different stakeholders (grieving children, educators and programme facilitators).

Setting: The grief programme is being implemented in four primary schools in Underberg and Himeville, rural KwaZulu-Natal, and this study will conduct an evaluation at all four sites.

Methods: Appreciative Inquiry, based on a four-dimensional cycle, was used to evaluate a grief programme offered in selected primary schools in KwaZulu-Natal, South Africa. Three stakeholder groups (grief support programme facilitators $[n=4]$, grieving children $[n=6]$ and educators $[n=2]$ ) from four schools were asked three open-ended questions to ascertain the programme's value.

Results: Nine key themes were identified: healing, insight, relationships, growth, skills, support, enjoyment, collaboration and value of the programme. All stakeholders noted positive outcomes resulting from participation in the programme and held it in high regard.

Conclusion: Improvements for its future development were suggested and recommendations made for its further implementation at schools throughout South Africa.

Keywords: grief; bereavement; programme evaluation; Appreciative Inquiry; learner intervention.

\section{Introduction}

In First World countries like the United States, Britain and Australia, grief intervention programmes are offered by organisations such as churches or non-governmental organisations (NGOs) as well as schools. After sampling 423 American public schools, Wass, Miller and Thornton (1999) found very little death education (11\%) and grief education (17\%) programmes being offered despite the National Association of School Psychologists providing resources and support for teachers and administrators (NASP 2015). McCarthy (2007) reports that even in Western societies there is still an inadequate knowledge and understanding regarding grief in learners because it is pushed aside and often considered to only affect a small portion of the population; however, unfortunately, it has been established that a significant proportion of learners will lose a family member before turning 18. Hence, McCarthy (2007) urges institutions offering expert interventions to learners to mobilise themselves and attend to the needs of this vulnerable group of population. In 2014, O'Brien and McGuckin (2014) found that the majority of teachers (over 85\%) in Ireland who participated in their study felt that a bereavement programme would benefit learners at schools and despite the resources there was very little implementation. In South African schools, organisations with indispensable expertise, need to be welcomed into schools to provide services which teachers either do not have time or the knowledge to implement.

In South African communities, family members take leave from work or school when they experience the loss of a close relative. The Department of Basic Education's Policy on Learner Attendance (RSA 2010: para. 7) recognises the role that the family plays on school attendance in terms of the responsibility of learners, especially if the learner is the head of the household. Slater and Bremmer (2003) and Kippa et al. (2010) refer to Maslow's basic needs (food and security), which lack tends to require more urgent attention than the emotional concerns of bereaved 
children. In rural environments, owing to the frequent lack of necessary levels of love, nurture and security, selfactualisation is often difficult to achieve.

Death and loss are familiar to many South African children and are complicated by poverty, HIV and AIDS and other social struggles. Loss is inevitable, and Levine and Kline (2007:221) explain that 'grief is a sense of loss and sorrow when someone or something we cherish is gone forever', after which life changes profoundly for those left behind. In rural KwaZulu-Natal (KZN) schools, the class size average was as high as 43 learners (Kwa Sani 2002), and more recently the KZN Department of Education in its Annual Performance Plan for 2011/2012 (2010) admitted that the learner-teacher ratio in KZN public schools is approximately 29:1. However, in certain schools wealthier parents pay higher school fees allowing for schools' governing bodies to hire additional teachers so that this may lower the learner-teacher ratio. Classrooms in poorer communities, therefore, tend to have learner-teacher ratios way above the national norm and teachers may not be possible to provide the individual emotional support that a child may require when negotiating the grieving process, and additional support is needed.

Ordinarily, children do not have the means to assimilate death into their present experience, and grieving adults around them are dealing with their own sense of loss. In these situations, children's emotional needs may not be given due consideration because adults are too busy or lack the skills to listen or explain the situation appropriately. Those involved with children, such as extended family, educational institutions or faith-based organisations, then need to take responsibility for educating learners about death, rather than assuming that someone else will (Kubler-Ross \& Kessler 2005).

Supporting learners through a grieving period deserves national attention to mitigate future mental health problems. The Khululeka Project (www.khululeka.org/impact) has estimated that South Africa has 1712677 maternal orphans; there is insufficient information for government to support the reality of grief and loss. Many orphans live in rural areas where resources are scarce and premature death is commonplace. The largely rural province of $\mathrm{KZN}$, for instance, was reported by Hall (2018) to have the highest proportion of vulnerable groups in South Africa, including 3.1\% (129 000) double orphans, 3.2\% (134 000) maternal orphans and 11\% (456 000) paternal orphans. The Khululeka Project (www.khululeka.org/impact) has also pointed out that there is a higher than average likelihood of health, social and educational complications, among grieving learners. These figures highlight the need for a network of support for grieving learners.

\section{Study of the literature}

Childhood has various daily stresses, such as friendships, academic pressures and peer pressure, but 'it is considered as a specific learning barrier for a child to lose a parent'
(Makhonza 2006:19). The grieving child reports the additional burden of finding life hard to cope with, feeling alone even when in company, feeling different to their peers, having trouble communicating their feelings, being harassed at school, experiencing guilt and deep despondency, and often feeling responsible for the surviving parent (Payne \& Rolls 2007).

According to Buglass (2010) and Yawa (2010), grief, mourning and bereavement are terms that are frequently used interchangeably, but grief is commonly understood as the inner experience of a person who has lost, to death, someone whom they loved. Bereavement is thus used to define a response when someone dies, and it may 'manifest itself through grief (intrapersonal experience) and mourning (external experience) (the) cultural displays of grief' (Yawa 2010:15).

Losing a parent has far-reaching consequences, but these may have to be deferred if there are more urgent stressors such as lack of finance. Lawhon (2004) warns that if grief reactions are suppressed, they surface when children face added pressures. Howard et al. (2006) point out that the psychosocial factors of death and children's adaptation have not been researched adequately in Africa, except for small studies conducted in Eastern Zimbabwe, Uganda and Tanzania, which found that orphans generally fell short, compared with their non-orphaned peers, in areas of finance, physical needs and psychosocial aspects of life and agreed that for orphans to recover they require psychosocial support, interventions for dealing with the grieving process and commemorative activities, and assistance in cases where parents were ill before they died because children derive benefit from preparation for loss (Cluver et al. 2012).

Shumba and Moyo (2014) caution that the death of a parent can lead to depression, which may impact a learner's social interactions, leaving him or her with further problems about which schools need to be aware. It is not uncommon for bereaved learners to struggle with varied psychosomatic symptoms and thoughts of suicide (Matteson 2008; Shumba \& Moyo 2014). At the Orphan Vulnerable Learners and Youth Conference (OVYC), Woollett (2013) expressed concern about orphans' vulnerability. Their frequent lack of healthy role models to teach them appropriate social skills can lead to anti-social behaviour patterns (De Witt \& Lessing 2010). Furthermore, grieving learners often regress in their development, feel fearful, display unstable emotions, change their social behaviour, experience sleep disturbances, blame themselves and feel guilty (Hilliard 2001).

Close by in Eastern Zimbabwe there are available support programmes, and a research study was pursued supplying learners who were grieving with pressing physical requirements such as nutrition, housing and education, rather than giving attention to the orphans' psychosocial needs (Howard et al. 2006). According to Shang (2007), there are numerous needs regarding the care of learners who have 
lost their parents, which still need to be addressed (psychosocial support and prevention of neglect).

If a learner receives the required support, future emotional health impediments could be reduced (Dent 2005). Following this principle, a non-governmental organisation (NGO), Vukuzakhe, in a rural area in KZN, has been attempting to meet the needs of bereaved learners by providing a supportive strategy to assist in the mourning process. Although the perceived benefits of Vukuzakhe have been highlighted by Flederman (2008), the programmehas not been independently evaluated.

White Paper 6: Building an Inclusive Education and Training System (DoE 2001) undertakes to ensure a co-ordinated approach involving different role players in education, affording all South African provinces a homogeneous inclusive education system within educational institutions. Ladbrook (2009) and Ebersohn and Eloff (2006) noted that the different role players invite collaboration with outside consultants, who arrange intervention and training programmes, identify orphans and provide them with programmes while simultaneously providing teachers with adequate training, support and information regarding referral processes for these learners.

Holborn and Eddy (2011) report that South Africa has an unstable family structure, and its history of apartheid, poverty and human immunodeficiency virus (HIV) and acquired immunodeficiency syndrome (AIDS) has had an immense impact on the general welfare of its population. This has placed a strain on children and extended family members, and many of the country's NGOs have initiated programmes to support orphans (Holborn \& Eddy 2011) who are fending for themselves. A General Household Survey by Statistics South Africa (2012) indicated that $63.6 \%$ of the learners received social grants and $94.2 \%$ of orphans aged 7-18 years were still attending school, so it is evident that a grief programme in schools is warranted.

In rural KZN schools, teachers were trying to 'manage' the emotional fallout of grieving learners who were struggling to cope with the loss of a parent(s). There was a dire need for this study, and the service provided by the NGO and Van Duuren (2002:7) found that when 'we consult children on what brings hope during times of bereavement and loss, their voices may in turn offer support to their adult caregivers and other people in the community'. With approximately 2 million HIV and AIDS orphans in South Africa (Chereni \& Mahati n.d.), it became clear that there was a growing population of young people who were grieving without any form of emotional support that may lead to long-term psychological problems.

Although research confirms the rising number of orphans worldwide, there is still insufficient information regarding the efficacy of interventions provided to these learners (Chatterji et al. 2010). Riley (2012) established that research is available regarding children's responses to death, but there is a scarcity regarding the effectiveness of grief support intervention and that group intervention strategies proved less daunting compared with individual counselling because they reduced feelings of despair and fretfulness and improved self-esteem and peer relationships. The literature (Garzouzie 2011) suggests that grief intervention for adolescents is most effective when provided within a school setting where learners feel secure and can express their interpretations of their situation while acquiring coping skills. In South Africa, with its limited resources, group therapy with a trained facilitator will provide greater access to grief counselling than a child might otherwise have within their community, adult support and a sense of belonging (immediately and possibly in the future) to group that understands. Within a group setting, facilitators can identify grievers who are experiencing extreme emotional anguish and refer for individual counselling.

O'Brien et al. (2011) acknowledge the valuable role that schools in Australia are playing in identifying, managing and supporting learners who are grieving, and these may be useful support structures such as counsellors and psychologists who can be called on for learners to be debriefed and encourage the expression of feelings in multiple ways, depending on the child's preferences. Such options are important for learners in South Africa.

Traditional talk therapy is vital, but Riley (2012) highlights the need for grief programmes to offer learners social support, at their specific developmental level, and utilise creative intervention strategies (such as play, drama or crafts) to generate an effective platform from which to discuss their loss and the associated emotions. Wong (2013) states that the efficacy of creative strategies is evident in the way grieving learners open up to their counsellor, freely share their feelings and work through their loss. Hilliard (2001) discovered that grief-stricken learners in a music therapy group not only had fewer grief symptoms, but their behavioural concerns also diminished. Barnes and Metel (2011) and Greenberg (2003) encourage the implementation of group counselling because learners are social beings and enjoy interacting with their peers. Being part of a group builds learner's self-esteem, they gain valuable learning experiences and recognise each other as role models gradually supporting members in the group. In essence, this is Vukuzakhe's goal.

Bushe (2011 citing Gergen 1978, 2009) mentions that Appreciative Inquiry (AI) is grounded in constructionist theory, which is a perspective that views human life as existing as it does, as a result of social and interpersonal influences (Owen 1995 citing Gergen 1985). Social constructionism also takes into account the influence of genetic inheritance, but places more emphasis on the influence of society on one's individual life and life within the community.

The aim of this study was to evaluate how this communitybased grief programme, which is implemented in schools, is 
perceived by three different sets of stakeholders: grieving learners, teachers and programme facilitators. A qualitative evaluation was conducted, utilising Appreciative Inquiry, (AI) to answer the following questions:

- What were the stakeholders' views, insights and attitudes regarding the grief programme?

- What were the perceived benefits of the programme for the stakeholders?

- What additions need to be made to the programme for it to be more effective?

\section{Research methods and design Study design}

The method used for this research study, to evaluate the effectiveness of a grief programme that was implemented in primary schools $(n=4)$ in $\mathrm{KZN}$, is AI. Appreciative Inquiry uses positive questions to facilitate encouraging transformation for stakeholders within an organisation (Cooperrider, Whitney \& Stavros 2008) as it assumes that in each structure there is something that is functioning correctly (Lewis \& Emil 2010) regardless of problems it may be experiencing. Using AI will provide participants, invested in either management, implementation or attending the programme, an opportunity to benefit from the evaluation process. Nel and Pretorius (2012) emphasise that AI supposes that all people (individual or groups) have talents, competencies and skills, which when harnessed bring about exciting possibilities so that they value their worth and feel enthused. Besides being culturally appropriate and ethical, it is also a fitting method to use with learners because it includes their contribution in a participatory manner (Ward 2011).

Maritz (2010) explains that the four-dimension transformational (4-D) model or cycle, developed at Case Western Reserve University by Cooperrider et al. (2008), reveals that $\mathrm{AI}$ allows members within an organisation to engage in dialogue about its competencies and assets, imagining its potentials and then considering future visions (Dunlap 2008). 'Appreciating' entails applying the 4-D cycle to determine, assess and focus on the positive elements that make an organisation worthy. The first step in the cyclical process is Discovery 'What gives life?' (The best of what is Appreciating); the second step is to Dream 'What might be?' (Imagine what the world is calling for - Envisioning); the third step in the cycle is the Design 'How can it be?' (Determining the ideal-Co-constructing) and the fourth and final step refers to Destiny 'What will be?' (How to empower, learn and adjust/improvise - Sustaining).

The programme that was evaluated was designed and developed by an NGO. The NGO trains facilitators to visit schools and work with learners whose family member or friend had recently died. The programme is group workbased and focuses on play and other interactive therapeutic activities that encourage learners to support each other through their emotionally difficult time. The facilitator liaises with a teacher in the school who assists with the identification of group participants and the grief group meets once a week, for 2 hours. The facilitator has a set of previously planned activities and the teacher sits in to provide support if necessary. The grief programme was implemented in primary schools in the Underberg and Himeville areas.

\section{Setting}

Non-probability, purposeful sampling was used. All four schools where the programme was implemented were involved in the study. The schools are based in rural KZN and learners have little or no access to resources unless these are made available at school.

\section{Study population and sampling strategy}

A total of 36 participants were selected to participate in the study: grief support programme facilitators $(n=4)$, who were trained to implement the programme, six learners from each of the four schools $(n=24)$ and two teachers from each school $(n=8)$. The six learners had recently experienced the loss of a parent and were currently grieving the loss. The teachers involved in the study had identified and referred the learners to the grief counselling programme.

\section{Data collection}

A questionnaire (Govender 2004) was distributed to each participant, asking three open-ended semi-structured questions, each highlighting the positive aspects of the programme, rather than focusing on deficits, to draw out positive social constructs. The researcher questioned participants using the solution-focused AI approach, and attempted to gain an in-depth understanding of the stakeholder's views and attitudes relating to the programme. Using three questions, the researcher collected data regarding the core context of the programme, so that the themes generated revealed the inner body of the programme. One of the reasons for selecting the questionnaire (Govender 2004) was that the three questions were worded to foster understanding of all three levels of participants.

Following the AI 4-D transformational development cycle, the following questions were used in the questionnaire (Govender 2004).

Question 1: 'Describe your experience of the programme'. This question relates to the discovery phase and encourages respondents to appreciate the best within the programme.

Question 2: 'What do you appreciate about the programme?' This question relates to the dream phase and encourages respondents to visualise promising prospects and reveal valuable aspects of the programme.

Question 3: 'How can the programme be improved?' This question concerns future dreams, and their completion, and the possibility to act on improvements. 


\section{Data analysis}

The data were thematically analysed, as suggested by Sullivan, Gibson and Riley (2012). All questionnaires were read cautiously and recurring themes identified (Demmer 2010), so data were analysed utilising the qualitative steps mentioned by Terre Blanche and Durrheim (2004): familiarisation and immersion, inducing themes, coding the data, elaboration, interpretation and checking. Elaboration, in thematic analysis, polishes the emerging themes and reveals the essence of the common responses discussed (Terre Blanche \& Durrheim 2004).

\section{Ethical considerations}

As outlined by De Vos et al. (2005), careful consideration should be given to the following areas of a research project: informed consent, confidentiality, right to withdraw, assessing risk of harm, deception, debriefing and honesty and integrity. Ethical clearance was sought from and granted by the Ethics Committee of the University of Zululand (Ethical Clearance number: UZREC 171110-030-RA Level 02). Before commencing the research, written permission was requested to use the questionnaire and consent was sought from various stakeholders to conduct the research (Department of Education's research department, the administrator of the NGO, Vukuzakhe of the grief programme, the liaison of the trainer Dlalanathi, facilitators of the programme and the parent or guardian of the learner as well as learner assent. Because of the sensitive emotional nature of this study, an intern psychologist was available to provide participants with psychological support should participation cause emotional distress. A local counselling psychologist also volunteered her services pro bono if the intern was not able to support participants adequately.

\section{Results}

\section{Significant themes}

\section{Healing}

The participants felt that the programme allowed learners to process their loss and adjust to life without the deceased. Healing brought with it a change (socially, emotionally and academically). Facilitators were often overwhelmed at the extent of the emotional hurt and healing experienced by the learners, as well as the impact of their work on the programme for healing:

'This time gives the children space to work through their grief.' (Participant F1, male, 36 years old)

'... they share everything with me.' (Participant F2, female, 40 years old)

'The programme helped them a lot because they feel healed now.' (Participant F3, female 32 years old)

The learners frequently expressed their intense confusion and pain, prior to attending the programme.

'When I was not participating in the programme I was not happy.' (Participant L4, female, age 10, Grade 5)

'Nowhere and no person makes as me as happy and some days I did not even go to school ...' (Participant L1, male, age 12, Grade 6)
The learners' emotional healing process required personal commitment, communicating in a group and the knowledge that they could trust others. Allowing for a sense of mastery to develop aids the emotional healing (Sagberg \& Roen 2011) process.

'It makes me feel better.' (Participant L5, male, age 11, Grade 5)

'We feel sad because it makes us remember and some days thinking not to come back because it makes me too sad in my heart.' (Participant L1, male, age 12, Grade 6)

'Some weeks remembering mommy is like knives pushing deep.' (Participant L6, female, age 11, Grade 5)

\section{Insight}

Participants agreed that healing occurred when learners gained insight into their situation. Prior to the programme learners were not given information regarding death, dying and the grieving process, and this led to feelings of abandonment, insecurity, guilt and hopelessness. Once learners were provided with information they felt free to commence with healing. Teachers involved in the programme understand the needs of their learners and how different types of interventions have helped them. Facilitators noticed that learners felt more comfortable to share their experience and emotions around death, dying and grief once they had more information on the topic. Being trained improved the facilitators' understanding of the children's grieving world, their intuition improved and they were able to better gauge children's needs. Facilitators also recognised that establishing rapport with learners is essential for a therapeutic relationship. Learners gained understanding of their loss and felt free to share their pain and trust others. The insight provided created an understanding of the internal motivations and struggles learners experience while trying to normalise grief and allowing learners to feel supported. Most learners reported relief on realising that other learners suffered loss too.

'... And understand more about my feelings and the situation I was facing.' (Participant L1, male, age 12, Grade 6)

But being a part of the group I understand, I understand lot about death and other people who are in same situation as me.' (Participant L2, female, age 10, Grade 5)

'...I have lost but have to let him go, it wasn't very easy to do that, because I loved him very much and I didn't understand why he has to go and leave me, ... ' (Participant L3, female, age 12 , Grade 6)

'...now I know that it was not my fault to lose my parents ...' (Participant L2, female, age 12, Grade 5)

'....and I know it helps to cry so let it out.' (Participant L4, female, age 11, Grade 5)

'The group gave me hope and more understanding when someone dies it is not the end of world.' (Participant L4, female, age 11, Grade 5)

'I'm very happy about so many things about myself things that I did not know about ...' (Participant L4, female, age 12, Grade 5)

'To be in this group has been special because I found out so much about myself.' (Participant L5, male, age 11, Grade 5) 
'I understand that even if my dad is not with me I still have all the good memories about him.' (Participant L3, female, age 11, Grade 5)

'... I feel that for the first time others understand me and understand I sometimes still miss my parents.' (Participant L2, female, age 10, Grade 5)

'I think it helps me understand death.' (Participant L1, male, age 12 , Grade 6)

\section{Relationships}

Every good relationship contributes something meaningful to an individual's life, but all the expectations and aspirations one may have for this connection are annihilated when a person dies (Stevenson \& Cox 2008 cited in Wlasenko 2009). The loss of a close relationship is what brought these learners to the grief group. Learners struggled to make sense of the loss, but when supported during the process of healing, relationships of trust were developed. Experiencing intense emotional pain in one's personal life can often cause disruptions within social situations. Learners often withdraw and initially work against those who are trying to offer them support. The majority of the teachers agreed that, prior to attending the programme, grieving learners struggled with relationships as they tried to cope with their loss. These behaviours created tension and were disruptive to the teaching and learning environment was time-consuming. After participation, teachers noticed the process fostered healthy relationships, emotions stabilised, and learners participated in activities and socialised with peers. Inappropriate social behaviour declined, and participation in the group programme improved relationships on several levels. Prior to attending the programme, learners admitted that they struggled with relationships:

'Sometimes I do not like playing with other children because my heart is in pain.' (Participant L1, male, age 12, Grade 6))

'In school there have been no friend for me and when I was attending the programme I had more friends.' (Participant L4, female, age 11, Grade 6)

After group therapy, learners were able to form bonds, which extended into the school. Learners also noticed that they were initially resistant to interacting with learners within the group, but with intervention trust and attachment was possible.

\section{Growth}

Emotional growth is closely linked to healing and facilitators either observed this in the learners or within themselves. Teachers indicated that before attending the programme, learners seemed stuck in their current stage of emotional development and this impacted negatively classroom behaviour.

'They did not enjoy being at school or even doing school work. They made sure they disrupt every lesson, seeking attention from teachers.' (Participant T1, female, Grade 6)

'Every lesson ended with these children crying or trying to get all of my attention. This doesn't happen since they attended the grief and bereavement group programme.' (Participant T2, female, Grade 5)

Barnard, Morland and Nagy (1999), who conducted a grief programme in Liverpool, United Kingdom, noted that there was an increase in self-esteem and coping skills when learners, while working alongside a facilitator, are part of a grief support group. Teachers also developed in their knowledge of the grief process:

'I see improvement in the children ...' (Participant T1, female, Grade 6)

'Most of the children are not moody or withdrawn anymore.' (Participant T2, female, Grade 7)

'The programme on its own builds the self-esteem of children.' (Participant T2, female, Grade 6)

'It builds the confidence of each learner.' (Participant T2, female, Grade 5)

'It seems the learners academic work improved.' (Participant T1, female, Grade 5)

Learners express grief differently to adults because they do not always have the vocabulary to express themselves (Traeger 2011).

'I don't know how my life would be because before I had so much anger and confusion ...' (Participant L4, female, age 11, Grade 5)

'If this programme was not at my school then my heart would still be crying, I would be sad(s) and maybe then my friend will weep saying I am always angry.' (Participant L5, male, age 12, Grade 6)

As learners spent more time in the programme, it was also noticed that their concentration improved within the classroom and their academic work was of a better quality. Learners were able to find a feeling of 'normality' (Barnard et al. 1999) and self-confidence.

\section{Skill acquisition}

Participants agreed that the facilitators' skills and abilities were exemplary and their training gave them confidence and coping ability. The training was valuable; teachers and learners found the facilitators' personal empathic qualities most impressive. There was agreement among teachers that the facilitators managed the programme professionally:

'Our facilitator has proved that she will take action immediately if a problem arises.' (Participant T1, female, Grade 5)

'I greatly appreciate the services and efficiency of our facilitator.' (Participant T2, male, Grade 7)

Teachers also agreed that learners developed coping mechanisms, which empowered them for daily encounters. 'Learners got tools to deal with emotional trauma'. The learners may have been unaware of the training facilitators underwent before implementing a programme, but they were aware of the facilitators' expertise when dealing with them:

'The group and my facilitator listened to my story with sensitivity and the care ...' (Participant L2, female, age 12, Grade 5) 
'The leader gives all group members the chance to speak and to get us to understand that if we speak we will feel better.' (Participant L5, male, age 10, Grade 5)

'Facilitators listened and cared about me.' (Participant L1, male, age 13 , Grade 7 )

'... to have somebody you don't know, come and show you how much they care for you and respect you and listen to what you say, it was amazing ...' (Participant L4, female, age 11, Grade 5 )

'... they are people who can be trusted and they have time for us ...' (Participant L6, male, age 12, Grade 7)

'... and showed me what to do on sad days.' (Participant L1, male, age 10, Grade 5)

'... there were some people there in time of sadness expressing care.' (Participant L3, female, age 13, Grade 7)

'I thank the facilitator lots for coming here to spend time with me and listened to what I have to say and showing kindness.' (Participant L5, male, age 12, Grade 5)

Learners were grateful for the support received and appreciative of the time and effort invested in them by the facilitators.

To assist a grieving learner does not necessarily require the services of a mental health professional. An adult who has the resolve and training may be able to provide support to the learner, to access an opportunity to express their sorrow and be strengthened to live a life without the deceased (Denis 2005). The facilitators used the skills acquired during training to provide a safe, enabling environment in which learners may heal emotionally. When a person is sincere, compassionate and approachable to the emotional pain grief brings to a learner's life this can go a long way to transverse the lonely journey of grief (Hildebrand 2005).

\section{Support}

Support is an important theme as it provides for the needs of the school system, teachers and the learners. Teachers recognised that support is needed for teaching sensitive topics because they acknowledge that their training does not equip them to respond adequately (Wood \& Goba 2011). However, Barnard et al. (1999) mention that teachers are also skilled and with basic training and awareness could be equipped to provide support to grieving learners. Learners remarked positively about the facilitators' positive attitudes when supporting them and agreed that support within the group was of importance:

'The more I listened to other people and they listened to me I realised they care and get their support and comfort and joy.' (Participant L1, female, age 11, Grade 6)

'The group gave me courage to face every situation.' (Participant L2, male, age 11, Grade 5)

'The Programme let me learn who can support me in life and how I can ask for help when I need it.' (Participant L5, female, age 11, Grade 5)

Support from the facilitator and others is closely linked to collaboration, which helps form a supportive network.

\section{Enjoyment}

Respondents agreed that activities were enjoyable. Creative techniques help learners to process grief in a developmentally appropriate manner. When dealing with bereaved learners in a therapeutic setting, they need to be treated primarily as children, rather than as people who are grieving (Barnard et al. 1999):

'... the programme is interactive and the learners enjoy the sessions and had fun.' (Participant T1, female, Grade 5)

'Learners enjoy going and this makes them participate freely and so they are benefitting.' (Participant T2, male, Grade 7)

The teachers felt that the programme addressed the developmental level of the children and agreed that learners needed no encouragement to attend.

\section{Collaboration}

Respondents agreed that working together had a positive impact on the needs of grieving learners. Collaboration within the school community improved interactions between staff and strengthened relationships (Dickerson \& Helm-Stevens 2011). Teachers invited the collaboration because they felt that they had insufficient support from educational authorities. Ebersohn and Eloff (2006) recognise that South African teachers have to face a wide range of daily challenges when it comes to grieving learners, which all stakeholders need to address. The theme of support is closely linked to collaboration because teachers believe that this NGO is filling a much-needed gap. Communication between the teachers and the NGO created an opportunity for the learners to heal and highlighted that they were not isolated in their grief. Learner participants' suggested that grief-learning programmes be used to support other learners. Some requested that a network of support be provided to other schools, their friends and family. According to Rogers (2007) who edited a series of books on death, dying and bereavement, learners need assistance from all members of society, not only close relatives, while they negotiate grief. Vukuzakhe's programme is encouraging support for this journey, using a variety of stakeholders.

\section{Value of the programme}

Once insight was expanded, respondents began to appreciate the programme and value the worthwhile contribution made on all levels. Respondents agreed that this programme was meaningful. Facilitators felt their work was emotionally draining but worthwhile; they made a difference to others' lives, which was personally satisfying. Teachers recognised that the programme alleviated emotional distress and impacted positively within the classroom:

'The programme helps kids to open up.' (Participant T1, female, Grade 6)

'We are most grateful to have been able to offer the children of our school this service.' (Participant T2, male, Grade 7)

Learners recognised that the programme had many personal benefits and appreciated the opportunities provided by attending the sessions: 
'This programme helped me very much.' (Participant L4, male, age 11, Grade 5)

'Appreciate help and support and Vukuzakhe brought this to my school so now all children and I do not feel so sad.' (Participant L1, male, age 13, Grade 7)

Corr (2016) mentions that while we may try to disregard our vulnerability as human beings, death and grief make us very aware of our mortality and susceptibility to sorrow and grief. However, this should not be translated as a weakness and learners should not be viewed as defenceless. Programmes on grief and bereavement highlight the strength and resilience inherent in children allowing them to cope under the most trying of circumstance.

\section{Discussion}

\section{Participants' suggestions for improvements}

The themes of healing, insight, relationships, growth, skill acquisition, support, enjoyment, collaboration and value of the programme were a preamble to the suggestions made by participants in the areas of improvements, so as to encourage extension of the programme. Ideally, AI as programme evaluation seeks to propel programmes into the future on a positive note.

\section{Follow-up}

Losing a parent is a difficult reality to process, but respondents recognised that losing the support of the group may be secondary trauma. Exit from the group needs to be gradual. After experiencing a programme where bonds of trust are established, a learner may experience a void; however, this may be managed with follow-up sessions as suggested by facilitators. Teachers mentioned the value of maintaining the caring relationship developed during the group sessions and that many behavioural, social and academic concerns dwindled when learners participated in the programme. Learners felt a complete restoration after participating in the programme and a few mentioned they would like a continued relationship with the facilitator, who played an integral role in their healing.

\section{Communication and feedback}

Teachers realised that through communication the adults involved in the programme can identify and discuss the regular needs or concerns of learners. This will support the grief resolution process and ensure that learners receive added support. Communication also includes broadening awareness of the programme. Facilitators appreciated the interaction with the school, especially teachers. Learners sometimes felt that there was a lack of support; nobody knew they had lost a parent and they waited for long periods before being included in the programme.

\section{Training and extension opportunities}

Teachers lacked confidence in their abilities to attend to grieving learners, but were willing to learn and meet with other schools to extend implementation of the programme. They also realised that the NGO will need funds to continue or expand the programme. The facilitators are generally satisfied with their training, but expressed the need for training of additional facilitators so that more learners are helped sooner. Learners wanted to see friends and siblings offered support. They bonded with the facilitator and requested additional healing experiences:

'Sport day with groups.' (Participant L1, male, age 13, Grade 7)
'Watch film about death.' (Participant L2, male, age 12, Grade 6)
'Going on a camp with the group and hiking.' (Participant L3,
female, age 11, Grade 6)

\section{Time allocation}

Participants felt the need for either more frequent gatherings or longer time allocation. Facilitators and teachers both agreed that additional time is needed. Learners admit that they would appreciate additional time or an extension of the programme.

\section{Continued support}

Continued support in the form of groups coming together within or across schools and expert support for extreme cases will provide additional benefits. Facilitators recognised the value of group support and suggested:

'... combining groups will let them realise they are not alone.' (Participant F3, female 32 years)

Teachers valued the impact of the NGO, but felt that key role players needed to offer their expertise because schools face a myriad of challenges daily:

'Department of Social Development and South African Police must be involved.' (Participant T1, male, Grade 7)

'... glad if we get more psychological support in our schools.' (Participant T2, female, Grade 6)

Learners want to repeat the programme and would also like to meet with learners from other groups in surrounding schools.

\section{Facilities}

Schools only have sufficient classroom space for teaching and learning, so there will be no privacy and confidentiality when learners receive support during teaching and learning time. The teachers recognised a need for improvement in this area.

\section{Additions to the programme}

Teachers expressed that authority figures needed to provide more support for the learners' psychosocial needs. In terms of Maslow's Hierarchy of Needs, the basic needs (food and security) of grieving learners are often tended to, but the emotional concerns may be neglected resulted in further complications later (e.g., behavioural and academic issues). Learners, who participated in the study and who required 
individual therapeutic intervention, need to receive individual therapeutic support. Because the programme catered only for group work, learner with serious problems may have to be catered for with individual sessions. Some learners waited long periods of time prior to being invited onto the programme after the loss of a parent and felt as if the school did not immediately acknowledge their loss. A system, which expedites the acknowledgement of learners' bereavement and provides learner support, needs to be included into the grief programme.

\section{Recommendations}

The following recommendations could lead to greater efficacy in the implementation of the programme. A consultative process between Vukuzakhe and the Department of Education (DoE) will increase the level of collaboration between stakeholders. Establishing partnerships with the Departments of Education, Health or Social Development and mental health practitioners would be advantageous for the NGO, so facilitators can discuss assistance they may require with curriculum development and referral of individual learners for support to relevant mental health providers. There is much that needs to be gained from networking with various stakeholders because the programme is in the early stages of implementation. Collaboration between schools (speaking at a school assembly, attendance at principal meetings and advocacy) to create awareness about and discuss the goals and content of the programme is needed. To further support learners, the NGO could offer workshops for teachers and guardians and train additional facilitators so that the programme may be extended to more schools in the area or even in terms of duration.

\section{Limitations}

Some limitations include cultural rituals specific to the locality. These impact the manner in which death is understood and processed (Mdleleni-Bookholane, Schoeman $\&$ Van der Merwe 2004). The research did not discern the cultural context of grief and how it may impact the stakeholders' perceptions of an intervention programme. Also, language barriers were not factored into the study and that participants' level of English competency differed at each school. This may have impacted the responses received. A focus group interview may have allowed for more clarity. This is particularly true when one considers that learners do not always have the vocabulary to express emotions or even ideas efficiently in written format. This discussion opportunity would also deepen the level of responses gained. The findings are limited and not generalisable to other projects.

\section{Conclusion}

If South Africa is to manage its grief situation, schools need to offer a more comprehensive intervention for learners experiencing intense loss and grief. This study encouraged participants to communicate positive views regarding programme evaluation. A solution-focused approach gives this programme energy (Gervase 2012), has stimulated awareness, highlighted the value the programme holds for the participants, as well as the need for this type of intervention within South Africa. It is hoped that the research may lead to the necessary changes for the organisation, as well as consolidation of their present strengths and further support for grieving orphans. As suggested by Griese, Burns and Farro (2018), there is still much research that needs to be conducted in the field of childhood grief and programme evaluation.

\section{Acknowledgements}

The researchers would like to thank the University of Zululand for support during the study, the management and staff at Vukuzakhe for their assistance and the participants at the schools.

\section{Competing interests}

The authors have no financial or personal relationships that have influenced them during the research study or writing of the article.

\section{Authors' contributions}

J.H. collated the data, wrote the literature review and analysed the data. S.G. conceptualised the study, assisted with the data analysis and was the corresponding author, which required considerable administrative responsibilities.

\section{Funding information}

This research received a grant from the National Research Foundation.

\section{Data availability statement}

Data sharing is not applicable to this article as no new data were created or analysed in this study.

\section{Disclaimer}

The views and opinions expressed in this article are those of the authors and do not necessarily reflect the official policy or position of any affiliated agency of the authors.

\section{References}

Barnard, P., Morland, I. \& Nagy, J., 1999, Children bereavement and trauma: Nurturing resilience, Jessica Kingsley Publishers, London.

Barnes, J. \& Metel, M., 2011, 'Peer-group support for bereaved children: A qualitative interview study', Child and Adolescent Mental Health 16(4), 201-207. https://doi. org/10.1111/j.1475-3588.2011.00601.x

Bushe, G.R., 2011, 'Appreciative Inquiry: Theory and critique', in D. Boje, B. Burnes \& J. Hassard (eds.), The Routledge companion to organizational change, pp. 87-103, Routledge, Oxford, UK.

Buglass, E., 2010, 'Grief and bereavement theories', Nursing Standard 24(41), 44-47.

Chatterji, M., Hutchinson, P., Buek, K., Murray, N., Mulenga, Y. \& Ventimiglia, M., 2010, 'Evaluating the impact of community-based interventions on schooling outcomes among orphans and vulnerable children in Lusaka, Zambia', Vulnerable Children and Youth Studies 5(2), 130-141. https://doi.org/10.1080/17450121003615351 
Chereni, A. \& Mahati, S.T., n.d., South Africa's response to orphans and vulnerable children, Extended summary of a literature review and workshop proceedings, viewed 07 August 2017, from https://www.google.com/url?sa=t\&rct=j\&q=\&esrc=s \&source $=$ web \&cd $=1 \&$ cad $=$ rja \&uact $=8 \&$ ved $=2$ ahUKEwji6LSP6 HeAhUm AcA AcAKHT2dCh4QFjAA egQIABAC\&url=https $\% 3$ A $\% 2$ F\%2 Fhgsf-global.
org\% $\% 2$ Fen $\% 2$ Fbank $\% 2$ Fdownloads $\% 2$ Fdoc download $\% 2$ F406-extended-reviewsituation-analysis-of-south-africas-response-to-orphans-and-vulnerablechildren\&usg=AOvVaw2UciTpF4Njlbe2IcLqpAz」

Cluver, L.D., Orkin, M., Gardener, F. \& Boyes, M.E., 2012, 'Persisting mental health problems among AIDS-orphaned children in South Africa', Journal of Child Psychology and Psychiatry 53(4), 363-370. https://doi.org/10.1111/j.1469-7610.2011.02459.x

Cooperrider, D.L., Whitney, D. \& Stavros, J.M., 2008, Appreciative Inquiry handbook: For leaders of change, 2 nd edn., Crown Custom Publishing, California.

Corr, C.A., 2016, 'Teaching about life and living in courses on death and dying', OMEGA Journal of Death and Dying 73(2), 174-187. https://doi.org/10.1177/00302228 15575902

Demmer, C., 2010, 'Experiences of women who have lost young children to AIDS in KwaZulu-Natal South Africa: A qualitative study', Journal of the International Aids Society 13(50), 1-9. https://doi.org/10.1186/1758-2652-13-50

Denis, P. (ed.), 2005, Never too small to remember: Memory work and resilience in times of AIDS, Cluster Publications, Pietermaritzburg.

Dent, A., 2005, Supporting the bereaved: Theory and practice. Counselling at work viewed 16 August 2017, from www.bacpworkplace.org.utc/journal-pdf/acw_ autumn05_ann.pdf.

Department of Basic Education (DBE), 2010, National Education Policy Act 27 of 1996 National Policy on Learner Attendance, Department of Basic Education, Pretoria.

Department of Education (DoE), 2001, Education White Paper 6: Special needs education: Building an inclusive education and training system, Department of Education, Pretoria.

De Vos, A.S., Strydom, H., Fouche, C.B. \& Delport, C.S.L., 2005, Research at grass roots: For the social sciences and human professions, 3rd edn., Van Schaik Publishers, Pretoria.

De Witt, M.W. \& Lessing, A.C., 2010, 'The psychosocial well-being of orphans in Southern Africa: The perception of orphans and teachers', The Journal for Transdisciplinary Research in Southern Africa 6(2), 461-477. https://doi. org/10.4102/td.v6i2.262

Dickerson, M.S. \& Helm-Scott, R., 2011, 'Reculturing schools for greater impact: Using Appreciative Inquiry as a non-coercive change process', International Journal of Business and Management 6(8), 66-73. https://doi.org/10.5539/ijbm.v6n8p66

Dunlap, C.A., 2008, 'Effective evaluation through Appreciative Inquiry', Performance Improvement 47(2), 23-29. https://doi.org/10.1002/pfi.181

Ebersohn, L. \& Eloff, I., 2006, 'Identifying asset-based trends in sustainable programmes which support vulnerable children', South African Journal of Education 26(3), 457-472.

Flederman, P., 2008, External evaluation report: Rob Smetherham bereavemen service for children, viewed 18 October 2016, from http://dlalanathi.org.za/ images/reports/Annual-report-2008.pdf

Garzouzie, G., 2011, 'The psychological experiences of grieving for adolescents recently bereaved of a parent', Master's dissertation, University of Stellenbosch, Stellenbosch.

Gervase, B., 2012, 'Foundations of appreciative inquiry: History, criticism and potential', Al Practitioner 14(1), 8-18.

Govender, S., 2004, 'Evaluating the lifeskills-based HIV and AIDS programme in schools: An Appreciative Inquiry', Doctoral thesis, University of Zululand KwaDlangezwa.

Greenberg, K.R., 2003, Group counselling in K-12 schools: A handbook for school counselors, Pearson Education, Boston, MA

Griese, B., Burns, M. \& Farro, S.A., 2018, 'Pathfinders: Promoting healthy adjustment in bereaved children and families', Death Studies 42(3), 134-142. https://doi.org/ 10.1080/07481187.2017.1370416

Hall, K., 2018, Statistics on children in South Africa: Orphaning, viewed 16 August 2017, from http://childrencount.uct.ac.za/indicator.php?domain=1\&indicator=4

Hildebrand, P., 2005, 'Primary school children's experiences in their loss of a parent' Master's dissertation, Nelson Mandela Metropolitan University, Port Elizabeth.

Hilliard, R.E., 2001, 'The effects of music therapy-based bereavement groups on mood and behaviour of grieving children: A pilot study', Journal of Music Therapy XXXVIII(4), 291-306. https://doi.org/10.1093/jmt/38.4.291

Holborn, L. \& Eddy, G., 2011, First steps to healing the South African family. Johannesburg. The South African Institute of Race Relations, viewed 13 May 2017, from https://ir org.za/reports/occasional-reports/first-steps-to-healing-the-south-african-family.

Howard, B., Matinhure, N., McCurdy, S.A. \& Johnson, C.A., 2006, 'Psychological disadvantage: Preparation, grieving, remembrance and recovery for orphans in Eastern Zimbabwe', African Journal of AIDS Research 5(1), 71-83. https://doi. org/10.2989/16085900609490368

Khululeka, n.d., Khululeka grief support: Why is this work important - Statistics, viewed 16 August 2017, from www.khululeka.org/impact.

Kippa, W.E., Satzinger, F., Alibhai, A. \& Rubbale, T., 2010, 'Needs and support for Ugandan child-headed households: Results from a qualitative study', Vulnerable Children and Youth Studies 5(4), 297-309. https://doi.org/10.1080/17450128.201 0.507805

Kubler-Ross, E. \& Kessler, D., 2005, On grief and grieving: Finding the meaning of grief through the five stages of loss, Simon and Schuster, London.
Kwa Sani, 2002, Integrated development plan, Udidi, Pietermaritzburg, environmental, planning and development consultants, viewed 20 September 2016, from http:// planning and development consultants, viewed 20 September 2016, from http://
kwasani.co.za/upload/KWA\%20SANI\%20IDP\%20-\%202012\%202016\%20Final.pdf.

KwaZulu-Natal Department of Education (DoE), 2010, Annual Performance Plan 2011/2012, Department of Education, KwaZulu-Natal.

Ladbrook, M.W., 2009, 'Challenges experienced by teachers in the implementation of inclusive education in primary schools in South Africa', Master's dissertation, University of South Africa, Pretoria.

Lawhon, T., 2004, 'Teachers and schools can aid grieving students', Education 124(3), 559-566.

Levine, P.A. \& Kline, M., 2007, Trauma through a child's eyes. Awakening the ordinary miracle of healing, North Atlantic Books, CA.

Lewis, R.E. \& Emil, S., 2010, 'Appreciative Inquiry: A pilot study of school counselor graduates', Journal of Humanistic Counseling, Education and Development 49(1), 98-111. https://doi.org/10.1002/j.2161-1939.2010.tb00090.x

Makhonza, L.O., 2006, 'Factors which contribute to orphaned learners' academic achievement', Master's dissertation, University of Zululand, KwaDlangezwa.

Maritz, G.U., 2010, 'An Appreciative Inquiry approach to community theatre on HIV and AIDS education for young people', Master's dissertation, University of Pretoria, Pretoria.

Matteson, R.E., 2008, 'Aids orphans in Zambia: Shattered hearts', Christian Century 125(18), 11-13.

McCarthy, J.R., 2007, 'They all look as if they're coping, but I'm not': The relationa power/lessness of "Youth" in responding to experiences of bereavement', Journa of Youth Studies 10(3), 285-303.

Mdleleni-Bookholane, T.N., Schoeman, W.J. \& Van der Merwe, I., 2004, 'The development of the understanding of the concept of death among black South African learners from the Eastern Cape, South Africa', Health SA Gesondheid 9(4), 3-14.

NASP School Safety and Crisis Response Committee, 2015, Addressing grief: Tips for teachers and administrators, National Association of School Psychologists, Bethesda.

Nel, H. \& Pretorius, E., 2012, 'Applying Appreciative Inquiry in building capacity in non-governmental organisation for youths: An example from Soweto, Gauteng, South Africa', Social Development Issues 34(1), 37-55.

O'Brien, A.M. \& McGuckin, C., 2014, 'Grieving students: The response and support of educators in Irish schools', Journal of Postgraduate Research, Trinity College Dublin 1, 159-176.

O'Brien, P., Mills, K., Fraser, A.F. \& Anderson, J., 2011, 'An invitation to grieve: reconsidering critical incident responses by support teams in the school setting', Australian Journal of Guidance and Counselling 21(1), 60-73. https://doi. org/10.1375/ajgc.21.1.60

Owen, I.R., 1995, 'El construccionismo social y la teoria, practica e investigacion en psicoterapia: Un manifiesto psicologia fenomenologica', transl. I. Caro, Boletin de Psicologia 46, 161-186.

Payne, A. \& Rolls, L., 2007, 'Children and young people's experience of UK childhood bereavement services', Mortality 12(3), 281-302. https://doi.org/10.1080/ 13576270701430585

Riley, A., 2012, 'Exploring the effects of the 'Seasons for Growth' intervention for pupils experiencing change and loss', Educational and Child Psychology 29(3), 38-53.

Rogers, J.E. (ed.), 2007, The art of grief: The use of expressive art in a grief support group: Series in death, dying and bereavement, Routledge, New York.

Sagberg, S. \& Roen, I., 2011, 'Social practices of encountering death: A discussion of spiritual health in grief and the significance of worldview', International Journal of Children's Spirituality 16(4), 347-360. https://doi.org/10.1080/1364436X.2011. 642854

Shang, X., 2007, 'The role of extended families in childcare and protection: The case of rural China', International Journal of Social Welfare 17(3), 204-215. https://doi. org/10.1111/j.1468-2397.2007.00531.x

Shumba, J. \& Moyo, G., 2014, 'Counselling needs of orphaned children: A case study of Harare Metropolitan children', Mediterranean Journal of Social Sciences 5(11) 145-155. https://doi.org/10.5901/mjss.2014.v5n11p145

Slater, A. \& Bremmer, G. (eds.), 2003, An introduction to developmental psychology, Blackwell Publishing, New York.

Statistics South Africa, 2012, General household survey, selected developmental indicators, Statistics South Africa, Pretoria.

Sullivan, C., Gibson, S. \& Riley, S. (eds.), 2012, Doing your qualitative psychology project, Sage, London.

Terre Blanche, M. \& Durrheim, K. (eds.), 2004, Research in practice: Applied methods for the social sciences, University of Cape Town Press, Cape Town.

Traeger, J, 2011, 'Supporting your grieving child', Journal of Palliative Medicine 14(1) 116-117. https://doi.org/10.1089/jpm.2010.9736

Van Duuren, L., 2002, 'Children's voices on bereavement and loss', Unpublished master's dissertation, University of South Africa, Pretoria, South Africa.

Ward, C., 2011, 'Building on the strengths of street children in Kampala, Uganda', A Practitioner 13(3), 45-52.

Wass, H., Miller, M.D. \& Thornton, G., 1990, 'Death education and grief/suicide intervention in the public schools', Death Studies 14(3), 253-268. https://doi. org/10.1080/07481189008252366

Wlasenko, A.E.G., 2009, 'The good grief workshop: A case study', Master's dissertation, University of Saskatchewan, Saskatoon, Canada. 
Woollett, N., 2013, 'Children and adolescents born with the HIV Virus', paper presented at the Orphan and Other Vulnerable Children and Youth (OVCY) Conference, Durban, South Africa, 27 May-02 June, viewed 16 August 2017, from http://www. google.co.za/url?sa $=t \& r c t=j \& q=\& e s r c=s \&$ source $=$ web $\& c d=1 \& c a d=r j a \& u a c t=8 \& v$ $\mathrm{d}=2$ ahUKEwjr6cbl9erhAhVStXEKHeLiCnEQFjAAegQIABAC\&url=http $\% 3 \mathrm{~A} \% 2 \mathrm{~F} \% 2 \mathrm{Fw}$ redspace.wits.ac.za\%2Fbitstream $\% 2$ Fhandle $\% 2$ F $10539 \% 2$ F $24845 \% 2$ FNalatly $\% 25$ 20Woollett $\% 2520-\% 2520$ PhD.pdf\%3Fsequence $\% 3$ D $1 \% 2$ isAllowed $\% 3$ Dy\&usg=A OvVaw39mNM2kfn8Ojvbz5CUYdFG.
Wong, K.C., 2013, 'Helping a child cope with loss by using grief therapy', Discovery - SS Student E-Journal 2, 195-215.

Wood, L. \& Goba, L., 2011, 'Care and support of orphaned and vulnerable children at school: Helping teachers to respond', South African Journal of Education 31, 275-290. https://doi.org/10.15700/saje.v31n2a484

Yawa, S.N., 2010, 'A psycho-analysis of bereavement in Xhosa, Zulu and Tswana cultures', Master's dissertation, University of South Africa, Pretoria. 